\author{
Grażyna Walczewska-Klimczak, dr \\ Biblioteka Narodowa \\ Pracownia Bibliotekoznawstwa Instytutu Książki i Czytelnictwa \\ gklimczak@uw.edu.pl
}

\title{
Typologia bibliotek szkolnych w gminach wiejskich w świetle badań własnych i Raportu o stanie bibliotek szkolnych w Polsce w 2012 r.
} Typology of school libraries in rural communities according to individual research and the Report on the condition of school libraries in Poland in 2012

Grażyna Walczewska-Klimczak - adiunkt w Pracowni Bibliotekoznawstwa Instytutu Książki i Czytelnictwa Biblioteki Narodowej. Zajmuje się bibliotekami szkolnymi. Zainteresowania naukowe: kultura, a w szczególności literatura dla dzieci i młodzieży oraz animacja czytelnictwa. Najintensywniej ze środowiskiem bibliotekarzy współpracowała w latach 1995-2005. W tym okresie realizowała i rozpowszechniała w całej Polsce cykl warsztatów dających bibliotekarzom narzędzia i umiejętności pozwalające na ożywienie bibliotek. Doświadczeniu warsztatowemu towarzyszyła stała praca dydaktyczna na Uniwersytecie Warszawskim w latach 1980-2012.

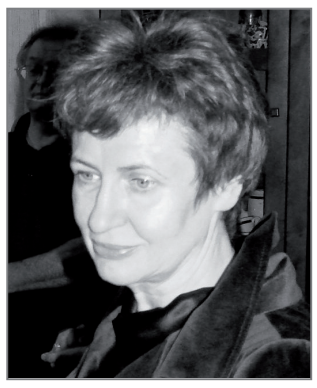

Wybrane publikacje:

- Animacja czytelnictwa dziecięcego. Koncepcje - doświadczenia - postulaty [Children readership animation. Concepts - experience - demands], 2004, [współred.]

- Model obstugi czytelniczej $w$ gminie [The model of the readership service in a small district] [w:] Budyńska B. (red.) z prezentacją wyników badań własnych zrealizowanych w $2012 \mathrm{r}$. [w przygotowaniu do druku].

Grażnna Walczewska-Klimczak - PhD, assistant professor in the Book and Readership Institute, National Library of Poland. Research interests: culture, school libraries, literature for children and youth, reading animation. She cooperated most intensively with the librarians in the years 1995-2005. That time she realized and promoted the series of workshops for librarians, offering them tools and skills to activate school and public libraries. Lecturer at the University of Warsaw in the years 1980-2012. 
W maju 2014 r. w Pracowni Bibliotekoznawstwa Instytutu Książki i Czytelnictwa Biblioteki Narodowej powstał raport Biblioteki w Polsce. Stan na 2012 r. Celem autorów raportu było opisanie głównych sieci/typów bibliotek w Polsce, ich stanu i tam, gdzie to możliwe, działalności oraz wskazanie głównych problemów, z jakimi mają do czynienia. Raport zawiera część poświęconą bibliotekom szkolnym (trzy wcześniejsze raporty dotyczące bibliotek szkolnych to: Raport o stanie bibliotek.. 1978; Stan bibliotek.. 1987; Piotrowska E., Rosiek S. (red.), 2012).

W artykule zostaną zaprezentowane najważniejsze dane zawarte w raporcie, które zgromadzono na bazie Systemu Informacji Oświatowej i które zostały przekazane przez Departament Analiz i Prognoz Ministerstwa Edukacji Narodowej w lutym $2014 \mathrm{r}$.

Relację o bibliotekach szkolnych poprzedzi niezbędna informacja o organizacji bibliotek w Polsce oraz ich liczbie. Na tym tle zostanie przedstawiona typologia bibliotek szkolnych, opracowana przez autorkę, a będąca efektem badań prowadzonych w Pracowni Bibliotekoznawstwa w 2012 r. w ramach tematu „Modele obsługi czytelniczej w gminie”.

\section{Organizacja bibliotek w Polsce}

Według obowiązującej ustawy, biblioteki mogą być tworzone i prowadzone przez: ministrów i kierowników urzędów centralnych, jednostki samorządu terytorialnego, a także osoby fizyczne, osoby prawne, jednostki organizacyjne nieposiadające osobowości prawnej. Biblioteki mogą być zorganizowane w formie samodzielnych jednostek organizacyjnych (np. biblioteki publiczne) albo jako część innej jednostki organizacyjnej (np. biblioteki szkolne, szkół wyższych) ${ }^{1}$.

Organizatorzy bibliotek mają obowiązek zapewnienia im odpowiednich warunków działania i rozwoju, w tym lokalu i wyposażenia oraz środków finansowych na prowadzenie działalności bibliotecznej, ze szczególnym uwzględnieniem zakupu materiałów bibliotecznych i na doskonalenie zawodowe pracowników.

Główny ciężar finansowania bibliotek spoczywa na samorządach, odpowiednich resortach oraz innych podmiotach. Państwo może wspierać działalność bibliotek poprzez przyznawanie dotacji celowych.

Stosując różne kryteria biblioteki łączyć można w grupy wyodrębnione np. ze względu na charakter i potrzeby środowiska, w którym działają, zakres tematyczny i formalny zbiorów, zasięg terytorialny działania, podstawy formalno-prawne

1 Według ustawy biblioteki publiczne powinny być zorganizowane w formie instytucji kultury, tzn. powinny posiadać osobowość prawną i finansową albo wchodzić w skład innej instytucji kultury (Ustawa z dnia 27 czerwca 1997 r...., poz. 642; Ustawa z dnia 25 października 1991 r., poz. 721, z późn. zm.). 
istnienia biblioteki, źródła finansowania i sposób udostępniania zbiorów; podział bibliotek ze względu na wymienione kryteria nie jest rozłączny.

Przyjmując jako element podziału mieszane kryterium - odbiorców usług bibliotecznych i profilu zbiorów - można wyodrębnić biblioteki: szkolne - $20363^{2}$, publiczne -8182 , parafialne - 1480 , naukowe - 1087 , fachowe - 369, pedagogiczne - 318, więzienne - 157, biblioteki wojskowo-oświatowe - 118, fachowo-beletrystyczne - 65, ośrodków informacji naukowej, technicznej i ekonomicznej -28 , towarzystw naukowych - 14. Łącznie w 2012 r. w Polsce prowadziło działalność $32181^{3}$ bibliotek.

\section{Wykres 1. Biblioteki w Polsce w 2012 r.}

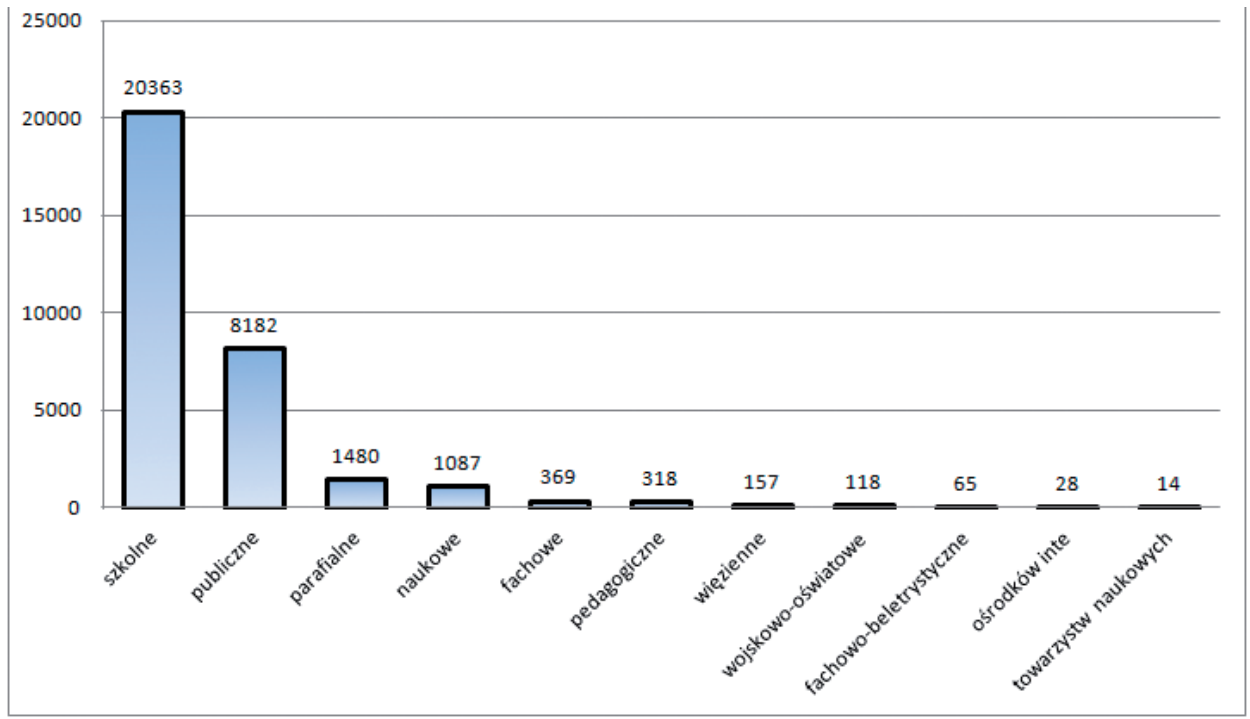

Źródło: oprac. własne na podst. Pracownia Bibliotekoznawstwa IKiCz BN. Raport o bibliotekach. Stan na 2012 r., 12.12.2014.

\section{Biblioteki szkolne w liczbach (wybór)}

Status prawny biblioteki szkolnej i nauczyciela bibliotekarza wyznaczają w Polsce przepisy oświatowe oraz biblioteczne. Podstawowe dokumenty prawne to: Ustawa o systemie oświaty (1991), Ustawa Karta Nauczyciela (1982), Ustawa o bibliotekach (1997).

${ }^{2}$ Dotyczy liczby bibliotek w: szkołach dla dzieci i młodzieży, szkołach dla dorosłych, szkołach artystycznych, bez szkół w podmiotach leczniczych, na podstawie danych z SIO, stan na 30.09.2012 r., przekazanych przez Departament Prognoz i Analiz MEN w lutym 2014 r.

313 bibliotek publicznych i 1 pedagogiczna o statusie naukowym zostały ujęte zarówno w sieci publicznej, pedagogicznej oraz wśród bibliotek naukowych. 
Informacje dotyczące bibliotek szkolnych zostały przygotowane na podstawie danych z Systemu Informacji Oświatowej według stanu na 30.09.2012 r. W Raporcie zaprezentowano ilościowy obraz:

- liczby bibliotek szkolnych i struktury ich dostępności w obrębie typów szkół,

- liczby pomieszczeń bibliotecznych i ich powierzchni,

- wielkości księgozbiorów z ograniczoną kategorią zbiorów specjalnych (książki mówione i inne materiały dydaktyczne nagrane na kasety audio, materiały dydaktyczne nagrane na kasety video, materiały dydaktyczne na nośnikach elektronicznych) oraz prenumerowane czasopisma,

- liczby komputerów w bibliotekach szkolnych (z dostępem do Internetu, z dostępem szerokopasmowym),

- liczby zatrudnionych nauczycieli-bibliotekarzy.

Wszystkie dane wykorzystane w Raporcie pochodzą z tzw. starego SIO, który nie obejmuje:

- liczby użytkowników (uczniów, nauczycieli i innych),

- skali wypożyczeń,

- struktury księgozbiorów ze względu na gatunki,

- zakupu nowości,

- wielkości i struktury ubytków,

- czasu pracy,

- liczby miejsc w czytelniach,

- liczby Internetowych Centrów Informacji Multimedialnej usytuowanych w bibliotekach szkolnych.

\section{Stan i dostępność bibliotek szkolnych w Polsce w 2012 r. - dane ogółem}

W roku szkolnym 2012/2013 w Polsce działało ogółem 34270 szkół, w tym 20363 szkoły (59,4\%) posiadały biblioteki szkolne, 7975 szkół (23,3\%) umożliwiało swym uczniom dostęp do biblioteki, a 5932 (17,3\%) nie posiadało ani biblioteki szkolnej, ani dostępu do biblioteki szkolnej.

Brak bibliotek szkolnych i dostępu do nich dotyczy przede wszystkim szkół dla dorosłych 3867 (64\%) i tym samym utrudnia dostęp do książki grupie 412867 ich uczniów $(73,5 \%)$.

W szkołach dla dzieci i młodzieży brak biblioteki szkolnej i dostępu do niej obejmuje 2050 szkół (7,3\% ogółu) i liczbę 153325 uczniów (3,3\% ogółu).

W Tabeli 2 podane zostały podstawowe liczby i wskaźniki opisujące stan wszystkich bibliotek szkolnych. 
Tabela 1. Liczba i odsetek szkół: z biblioteką, z dostępem do bibliotek oraz bez bibliotek i dostępu do bibliotek w ramach jednostki złożonej w szkołach: dla dzieci i młodzieży, dla dorosłych, artystycznych

\begin{tabular}{|c|c|c|c|c|c|c|c|c|}
\hline \multirow[t]{3}{*}{$\begin{array}{l}\text { Szkoły wg } \\
\text { kategorii uczniów }\end{array}$} & \multirow{3}{*}{$\begin{array}{l}\text { Liczba } \\
\text { szkół } \\
\text { ogółem }\end{array}$} & \multicolumn{5}{|c|}{$\begin{array}{l}\text { Szkoły posiadające biblioteki/ } \\
\text { dostęp do biblioteki }\end{array}$} & \multirow{2}{*}{\multicolumn{2}{|c|}{$\begin{array}{l}\text { Szkoły nie posia- } \\
\text { dające bibliotek } \\
\text { ani dostępu do } \\
\text { bibliotek }\end{array}$}} \\
\hline & & \multirow[t]{2}{*}{$\begin{array}{l}\text { Ogółem } \\
\text { (suma } \\
\text { kolumn } \\
\text { 4 i 6) }\end{array}$} & \multicolumn{2}{|c|}{$\begin{array}{l}\text { Liczba bibliotek } \\
\text { szkolnych (tzn. } \\
\text { szkoły posiadające } \\
\text { bibliotekę) }\end{array}$} & \multicolumn{2}{|c|}{$\begin{array}{l}\text { Wyłącznie } \\
\text { z dostępem do } \\
\text { bibliotek }\end{array}$} & & \\
\hline & & & liczba & $\%$ & liczba & $\%$ & liczba & $\%$ \\
\hline$-1-$ & $-2-$ & $-3-$ & $-4-$ & $-5-$ & $-6-$ & $-7-$ & $-8-$ & $-9-$ \\
\hline ogółem* & 34270 & 28338 & 20363 & 59,4 & 7975 & 23,3 & 5932 & 17,3 \\
\hline $\begin{array}{l}\text { Szkoły dla dzieci } \\
\text { i młodzieży }\end{array}$ & 28107 & 26057 & 19713 & 70,1 & 6344 & 22,6 & 2050 & 7,3 \\
\hline $\begin{array}{l}\text { Szkoły } \\
\text { dla dorosłych }\end{array}$ & 6042 & 2175 & 594 & 9,8 & 1581 & 26,2 & 3867 & 64,0 \\
\hline $\begin{array}{l}\text { Ogólnokształcace } \\
\text { szkoły artystyczne }\end{array}$ & 121 & 106 & 56 & 46,3 & 50 & 41,3 & 15 & 12,4 \\
\hline
\end{tabular}

Źródło: oprac. własne na podst. danych MEN, Departament Analiz i Prognoz, 12.02.2014.

* bez szkół przy podmiotach leczniczych

\section{Tabela 2. Biblioteki szkolne 2012 - liczby, wskaźniki}

\begin{tabular}{|l|r|}
\hline $\begin{array}{l}\text { Biblioteki szkolne ogółem w szkołach dla dzieci i młodzieży, w szkołach } \\
\text { dla dorosłych i w ogólnokształcących szkołach artystycznych }\end{array}$ & 20363 \\
\hline Liczba szkół & $34270^{*}$ \\
\hline $\begin{array}{l}\text { Liczba uczniów w szkołach, w których funkcjonują biblioteki/w szkołach } \\
\text { z dostępem do bibliotek }\end{array}$ & 4689182 \\
\hline Liczba książek w bibliotekach szkolnych & 153138659 \\
\hline Liczba osób pełniących obowiązki nauczyciela bibliotekarza & 22397 \\
\hline Średnia liczba pomieszczeń na 1 bibliotekę szkolną & 1,3 \\
\hline Średnia liczba książek na 1 bibliotekę szkolną & 7520,4 \\
\hline Średnia liczba uczniów na 1 bibliotekę szkolną & 230,3 \\
\hline Średnia powierzchnia na 1 bibliotekę szkolną w m² & 51,0 \\
\hline Średnia liczba tytułów prenumerowanych dzienników i czasopism na 1 bibliotekę & 4,5 \\
\hline Średnia liczba komputerów użytkowanych przez uczniów w 1 bibliotece szkolnej & 2,9 \\
\hline Średnia liczba komputerów z dostępem do Internetu w 1 bibliotece szkolnej & 2,8 \\
\hline $\begin{array}{l}\text { Średnia liczba komputerów z dostępem do szerokopasmowego Internetu } \\
\text { w 1 bibliotece szkolnej }\end{array}$ & 1,9 \\
\hline
\end{tabular}

Źródło: oprac. własne na podst. danych MEN, Departament Analiz i Prognoz, 12.02.2014.

* bez szkół przy podmiotach leczniczych 


\section{Biblioteki w szkotach dla dzieci i mtodzieży 4}

Liczba bibliotek szkolnych w szkołach dla dzieci i młodzieży - 19 713; średnia powierzchnia biblioteki - 51,6 m²; średnia wielkość księgozbioru na jedną bibliotekę - 7 634,3 wol.; średnia liczba książek na 1 ucznia - 33,3 wol. ${ }^{5}$; średnia liczba prenumerowanych tytułów dzienników i czasopism - 4,6; średnia liczba komputerów w bibliotece do użytku uczniów z dostępem do Internetu - 2,9 (dane MEN, Departament Analiz i Prognoz).

Dbałością o obecność bibliotek szkolnych w szkołach oraz o dostęp uczniów do bibliotek szkolnych w sposób nierównomierny wykazują się organy prowadzące szkoły. Organami prowadzącymi wszystkie rodzaje szkół są w przeważającej większości jednostki samorządu terytorialnego, które finansują zadania oświatowe z subwencji otrzymywanej z budżetu państwa. Jednak w ostatnich latach mamy do czynienia z sytuacją przejmowania obowiązków prowadzenia szkół przez organizacje społeczne, stowarzyszenia oraz organizacje wyznaniowe. Jak podaje Raport o stanie edukacji 2012 (2013, s. 20) od 2000 r. udziały podmiotów innych niż samorządy i administracja rządowa w prowadzeniu szkół wzrosły niemal trzykrotnie. Największy udział wśród tych szkół mają placówki prowadzone przez organizacje społeczne i stowarzyszenia. W 2012 r. prowadziły one 1762 szkoły dla dzieci i młodzieży wszystkich typów, co stanowi $6,3 \%$ ogółu szkół. Ma to o tyle znaczenie, że te organy mogą swobodniej kształtować wielkość i strukturę zajęć ponad wymagane minimum, jak i nakłady na nie, w tym te odnoszące się do zatrudnienia i wyposażenia. Dotyczyć to może również potencjalnie organizacji pracy oraz zasobów bibliotek szkolnych. Jednak, jak obrazują dane zawarte w Tabeli 3, prezentującej szkoły według organów prowadzących, aż 28,8\% szkół organizacji społecznych i stowarzyszeń nie posiada bibliotek szkolnych i nie zapewnia dostępu do nich. Stanowi to utrudnienie dla 25\% uczniów uczących się w szkołach prowadzonych przez te organy, czyli dla 24629 osób. Zaś organizacje wyznaniowe jako organizatorzy szkół nie zapewniają prawie w 1/3 swoich szkół kontaktu uczniów z książką i informacją w bibliotece szkolnej. Ten sam problem mają pozostali organizatorzy (osoby prywatne, spółki z o.o.), w szkołach których aż 34054 uczniów (prawie 40\%) nie ma zapewnionej możliwości dostępu do bibliotek szkolnych.

W roku 2012/2013 łącznie w Polsce 4,4\% szkół było prowadzonych przez podmioty prywatne (1 237 szkół dla dzieci i młodzieży). Prawie połowa tych szkół $(48,3 \%)$ nie miała biblioteki szkolnej.

${ }^{4}$ Ze względu na temat przewodni książki w dalszej części rozważań pomięto biblioteki w szkołach dla dorosłych i szkołach artystycznych.

${ }^{5}$ Liczone dla uczniów w szkołach posiadających bibliotekę/dostęp do biblioteki. 
Tabela 3. Liczba szkół: $\mathrm{z}$ biblioteką, $\mathrm{z}$ dostępem do bibliotek oraz bez bibliotek i dostępu do bibliotek $w$ ramach jednostki złożonej w szkołach dla dzieci i młodzieży wg organu prowadzącego

\begin{tabular}{|c|c|c|c|c|c|c|}
\hline \multirow[t]{3}{*}{ Organ prowadzący } & \multirow{3}{*}{$\begin{array}{l}\text { Liczba } \\
\text { szkół } \\
\text { ogółem }\end{array}$} & \multicolumn{3}{|c|}{$\begin{array}{l}\text { Szkoły posiadające biblioteki/ } \\
\text { dostęp do biblioteki }\end{array}$} & \multirow{2}{*}{\multicolumn{2}{|c|}{$\begin{array}{c}\text { Szkoły } \\
\text { bez bibliotek } \\
\text { i dostępu do } \\
\text { bibliotek }\end{array}$}} \\
\hline & & \multirow{2}{*}{$\begin{array}{l}\text { Ogółem } \\
\text { (suma } \\
\text { kolumn } \\
\text { 4 i 5) }\end{array}$} & \multirow{2}{*}{$\begin{array}{c}\text { Liczba biblio- } \\
\text { tek szkolnych } \\
\text { (tzn. szkoły } \\
\text { posiadające } \\
\text { bibliotekę) }\end{array}$} & \multirow{2}{*}{$\begin{array}{l}\text { Wyłącznie } \\
\text { z dostę- } \\
\text { pem do } \\
\text { bibliotek }\end{array}$} & & \\
\hline & & & & & liczba & $\%$ \\
\hline$-1-$ & $-2-$ & $-3-$ & $-4-$ & $-5-$ & $-6-$ & $-7-$ \\
\hline Ogółem & 28107 & 26057 & 19713 & 6344 & 2050 & 7,3 \\
\hline $\begin{array}{l}\text { Organy } \\
\text { administracji rządowej }\end{array}$ & 193 & 190 & 105 & 85 & 3 & 1,5 \\
\hline $\begin{array}{l}\text { Jednostki samorządu } \\
\text { terytorialnego }\end{array}$ & 24572 & 23724 & 17715 & 6009 & 848 & 3,5 \\
\hline $\begin{array}{l}\text { Organizacje społeczne } \\
\text { i stowarzyszenia }\end{array}$ & 1762 & 1254 & 1131 & 123 & 508 & 28,8 \\
\hline Organizacje wyznaniowe & 343 & 249 & 187 & 62 & 94 & 27,4 \\
\hline Pozostali organizatorzy & 1237 & 640 & 575 & 65 & 597 & 48,3 \\
\hline
\end{tabular}

Źródło: oprac. własne na podst. danych MEN, Departament Analiz i Prognoz, 12.02.2014.

Analiza zestawienia (por. Tabela 3) potwierdza, że zarówno organy administracji rządowej w 98,4\%, jak i jednostki samorządu terytorialnego w 96,5\% wywiązują się z ustawowego obowiązku zapewnienia dzieciom i młodzieży dostępu do biblioteki szkolnej. Problem braku biblioteki/dostępu do biblioteki dotyczy jednak 851 szkół obydwu wymienionych organizatorów i 87731 uczących się w nich uczniów.

Trzy pozostałe organy prowadzące szkoły mają o wiele więcej do nadrobienia.

\section{Dostępność bibliotek szkolnych w szkołach dla dzieci i młodzieży}

W porównaniu z rokiem szkolnym 2010/2011, w którym liczba bibliotek szkolnych wynosiła 19 822, w roku 2012 odnotowano spadek liczby bibliotek szkolnych o 109.

W 2012 r. w szkołach dla dzieci i młodzieży w Polsce funkcjonowało łącznie $19713^{6}$ bibliotek szkolnych, w tym 12012 usytuowanych było w szkołach pod-

${ }^{6} \mathrm{~W}$ tej liczbie mieszczą się łączone biblioteki publiczno-szkolne, które nie są w statystyce SIO specjalnie wyodrębniane. W 2012 r. takich bibliotek było 167 (Biblioteki Publiczne w Liczbach 2012 BN, na prawach maszynopisu). 
stawowych, 4276 w gimnazjach, 1526 w liceach ogólnokształcących oraz 1326 w technikach.

Brak biblioteki lub dostępu do biblioteki szkolnej w szkołach dla dzieci i młodzieży, to zjawisko, które w nierównomiernym nasileniu dotyczy różnych typów szkół.

Gorszą sytuację w dostępie do książek i innych informacji w bibliotekach szkolnych mają zdecydowanie szkoły policealne, szkoły przysposabiające do pracy oraz, w mniejszym stopniu, gimnazja i licea ogólnokształcące.

Należy zauważyć, że we wszystkich typach szkół dla dzieci i młodzieży (oprócz szkół specjalnych przysposabiających do pracy i szkół policealnych), tak odsetek szkół, jak i odsetek uczących się w nich uczniów, którzy mają zapewniony kontakt z książką i innymi źródłami informacji w bibliotekach szkolnych wynosi powyżej $90 \%$.

Jednak prawie co dziesiąte gimnazjum dla młodzieży i co dziewiąte liceum dla młodzieży w Polsce pozbawione jest biblioteki i dostępu do biblioteki.

W przypadku gimnazjów dotyczy to 56343 uczniów (4,9\% ogółu gimnazjalistów w Polsce), a w przypadku liceów 12392 uczniów (2,1\% ogółu licealistów). Na łączną liczbę 153325 uczniów w polskich szkołach, pozbawionych możliwości kontaktu z książką w szkolnej bibliotece, składają się jeszcze: 57548 uczniów szkół podstawowych, 7846 uczniów zasadniczych szkół zawodowych, 7395 uczniów techników i 10165 uczniów szkół policealnych dla dzieci i młodzieży. Pozostała grupa 1636 uczniów to młodzież z: liceów profilowanych, liceów uzupełniających, techników uzupełniających oraz szkół specjalnych przysposabiających do pracy.

\section{Lokale bibliotek szkolnych}

$\mathrm{Z}$ analizy zestawień dotyczących liczby i powierzchni lokali przypadających łącznie na 19713 bibliotek szkolnych w 2012 r. wynika, że średnio na 1 bibliotekę szkolną przypada 1,3 pomieszczenia (bez zmian w porównaniu z 2010 r.), a przeciętna powierzchnia jednej biblioteki szkolnej w szkołach dla dzieci i młodzieży w skali całej Polski to $51,6 \mathrm{~m}^{2}$ (spadek o 1,5 $\mathrm{m}^{2}$ w porównaniu z 2010 r.). Warunki lokalowe bibliotek szkolnych w ciągu dwóch lat nieznacznie, ale pogorszyły się. Powierzchnia bibliotek szkolnych jest zróżnicowana w zależności od typu szkoły oraz środowiska, w którym szkoła funkcjonuje.

Biblioteki w polskich szkołach są zbyt małe, jak na wielość i zakres stawianych przed nimi zadań, definiowanych również w podstawie programowej. Jeśli to możliwe nauczyciele bibliotekarze starają się wydzielić i utrzymać podział na czytelnię i wypożyczalnię. Zdecydowanie gorsza jest sytuacja bibliotek szkolnych na wsi, gdzie prawie we wszystkich typach szkó średnia liczba pomieszczeń i śred- 
nia powierzchnia jest poniżej średniej dla bibliotek szkolnych w całej Polsce. Wyjątkiem są wiejskie licea i technika, ale te również mają gorsze warunki lokalowe w porównaniu z ich miejskimi odpowiednikami.

Ponadto wyraźna jest ogólna tendencja gorszej sytuacji lokalowej bibliotek szkół podstawowych i gimnazjów. Licea ogólnokształcące i technika mają zdecydowanie lepsze zaplecze do realizacji stawianych bibliotece szkolnej zadań.

\section{Zbiory bibliotek szkolnych}

Stan zasobów księgozbiorów bibliotek szkolnych w dniu 30.09.2012 r. wynosił 150494840 książek, liczba prenumerowanych tytułów dzienników i czasopism - 90 574, pozostałe zbiory na innych nośnikach to łącznie 2496123 jednostki. Średnia wielkość księgozbioru na jedną bibliotekę w Polsce wynosi 7 634,3 książki. W miastach przeciętnie biblioteka szkolna liczy 10 516,7 książki, a na wsi 5010,2 .

Z danych zamieszczonych w SIO wynika, że zasoby książek, pozostałych zbiorów i czasopism są mniejsze w bibliotekach w gimnazjach, szkołach podstawowych i zasadniczych zawodowych w środowisku wiejskim niż w szkołach miejskich. Dotyczy to również bibliotek liceów profilowanych, liceów uzupełniających i szkół specjalnych, ale na wsiach stanowią one grupę tylko 11 szkół. Generalnie potwierdza się fakt lepszego wyposażenia bibliotek w szkołach ponadgimnazjalnych w miastach, zwłaszcza w mniejszych ośrodkach miejskich.

Zbiory bibliotek szkolnych w skali całego kraju wykazują w swoich statystykach systematyczny wzrost. Należy jednak ostrożnie szacować jakość księgozbiorów, którymi dysponują biblioteki. Sami nauczyciele bibliotekarze podkreślają, że zbyt duża wielkość księgozbioru często jest wynikiem braku przeprowadzania systematycznej selekcji. I nie jest to związane z niechęcią do związanego z tym trudu. Przede wszystkim jest to podyktowane względami pragmatycznymi. 1 stycznia 1999 r. zostało uchylone Zarzadzenie Ministra Edukacji Narodowej z dnia 4 czerwca 1997 r., w którym zawarte były regulacje prawne w sprawie liczby uczniów, na których przysługuje etat nauczyciela bibliotekarza. Uchylonego zarządzenia nie zastąpiono innymi, dlatego też organizatorzy szkół w poszukiwaniu kryteriów decydujących o wymiarze zatrudnienia nauczyciela bibliotekarza często wskazują wielkość księgozbioru. W tej sytuacji zarówno dyrektorzy szkół, jaki i sami nauczyciele bibliotekarze nie są zainteresowani zredukowaniem stanów księgozbiorów. Wycofanych książek ze względu na niskie kwoty przeznaczane na zakup nowości (których nie wykazuje się w statystyce SIO, ale o których alarmują bibliotekarze szkolni), nie ma czym zastąpić.

Należy ponadto zauważyć, że programy rządowe w skali całej Polski, wspierające zakup nowości do szkolnych bibliotek pojawiły się dopiero od połowy $2014 \mathrm{r}$. 
Jako pierwsze Ministerstwo Kultury i Dziedzictwa Narodowego (MKiDN) uruchomiło pilotażowy projekt Zakup nowości wydawniczych do bibliotek publicznych zgodnie z potrzebami partnerskich bibliotek szkolnych - Priorytet $2 \mathrm{z}$ budżetem 3000000 zł. $^{7}$

W styczniu 2015 r. Ministerstwo Edukacji Narodowej zainicjowało program „Książki naszych marzeń", w ramach którego do szkół trafi $15 \mathrm{mln}$ zł z jego budżetu na zakup nowości wydawniczych dla bibliotek. Program przewiduje na ten cel 20-procentowy wkład własny samorządów, dzięki temu na zakupy dla bibliotek szkolnych zostanie przeznaczone łącznie $18 \mathrm{mln}$ zł. W pierwszej kolejności adresatem programu będą biblioteki szkół podstawowych i ogólnokształcących szkół muzycznych I stopnia. Program "Ksiażki naszych marzen”” jest traktowany jako początek realizacji wspólnie z Ministerstwem Kultury i Dziedzictwa Narodowego wieloletniego Narodowego Programu Rozwoju Czytelnictwa Narodowego w latach 2016-2020. W tej sprawie w styczniu 2015 r. Minister Kultury i Dziedzictwa Narodowego Małgorzata Omilanowska oraz Minister Edukacji Narodowej Joanna Kluzik-Rostkowska podpisały list intencyjny (Informacje i Aktualności [online]).

\section{Struktura bibliotek szkolnych ze względu na wielkość księgozbiorów}

Do zaprezentowania struktury bibliotek szkolnych ze względu na wielkość zasobów ich bibliotek przyjęliśmy standardowe kategorie wielkości stosowane w Polsce przez GUS (por. Tabela 4).

\section{Tabela 4. Biblioteki szkolne według wielkości księgozbioru}

\begin{tabular}{|c|c|c|c|c|c|c|c|c|c|}
\hline \multirow{2}{*}{$\begin{array}{l}\text { Wyszcze- } \\
\text { gólnienie }\end{array}$} & \multicolumn{9}{|c|}{ Księgozbiór w woluminach } \\
\hline & $\begin{array}{l}2000 \\
\text { i mniej }\end{array}$ & $\begin{array}{c}2001- \\
5000\end{array}$ & $\begin{array}{l}5001- \\
10000\end{array}$ & $\begin{array}{c}10001 \\
-15000 \\
\end{array}$ & $\begin{array}{r}15001 \\
-20000 \\
\end{array}$ & $\begin{array}{c}20001 \\
-30000 \\
\end{array}$ & $\begin{array}{c}30001 \\
-50000 \\
\end{array}$ & $\begin{array}{l}50000 \\
\text { i więcej }\end{array}$ & Razem \\
\hline $\begin{array}{l}\text { Ogółem } \\
\%\end{array}$ & $\begin{array}{r}3077 \\
15,7\end{array}$ & $\begin{array}{r}5890 \\
\mathbf{3 0 , 0}\end{array}$ & $\begin{array}{r}5387 \\
27,4\end{array}$ & $\begin{array}{r}2923 \\
14,9\end{array}$ & $\begin{array}{r}1403 \\
7,1\end{array}$ & $\begin{array}{r}748 \\
3,8\end{array}$ & $\begin{array}{r}176 \\
\mathbf{0 , 9}\end{array}$ & $\begin{array}{r}31 \\
\mathbf{0 , 2}\end{array}$ & $\begin{array}{l}196358 \\
\mathbf{1 0 0 , 0}\end{array}$ \\
\hline Miasto & 1015 & 1494 & 2483 & 2217 & 1241 & 708 & 165 & 26 & 9349 \\
\hline Wieś & 2062 & 4396 & 2904 & 706 & 162 & 40 & 11 & 5 & 10286 \\
\hline
\end{tabular}

Źródło: oprac. własne na podst. danych MEN, Departament Analiz i Prognoz, 12.02.2014.

${ }^{7}$ Zakup nowości wydawniczych do bibliotek publicznych zgodnie z potrzebami bibliotek szkolnych w roku 2014 wynosi 3 mln zł. Zatwierdzony przez Ministra Kultury i Dziedzictwa Narodowego budżet Priorytetu 2 Programu BN Zakup nowości wydawniczych do bibliotek (Programy i ustugi [online]).

${ }^{8}$ Różnica 78 bibliotek w porównaniu z ogólną liczbą bibliotek szkolnych w szkołach dla dzieci i młodzieży, czyli liczbą 19713 , wynika z faktu wykazania przez szkoły w SIO posiadania biblioteki, ale bez podania wielkości księgozbioru. Dotyczy to wyłącznie bibliotek w szkołach wiejskich. 
$30 \%$ bibliotek w polskich szkołach mieści się w grupie bibliotek liczących od 2 do 5 tys. książek, przy czym 3/4 bibliotek tej grupy stanowią biblioteki w szkołach wiejskich. Kolejna grupa najliczniejszych bibliotek (27,4\%) ma księgozbiory pomiędzy 5 a 10 tys. woluminów. W tej grupie również liczniejsze są biblioteki szkół wiejskich. Kolejne dwie grupy są prawie równoliczne, bo 15,7\% to biblioteki o najmniej licznych księgozbiorach (również w tej grupie są dwa razy liczniejsze biblioteki szkolne w środowisku wiejskim) oraz prawie 15\% bibliotek z książkami pomiędzy liczbą 10001 a 15000 . W pozostałych, bogatszych w księgozbiory bibliotekach liczniejsze są te usytuowane w szkołach miejskich.

\section{Komputery w bibliotekach szkolnych}

W 2012 r. na wyposażeniu bibliotek szkolnych było 58179 komputerów dostępnych dla uczniów, czyli średnio 3 komputery na jedną bibliotekę szkolną. Wobec jasno formułowanych zadań, stanowiących o bibliotece szkolnej jako wyspecjalizowanej pracowni zdolnej wspierać uczniów, nauczycieli i członków środowiska lokalnego w pozyskiwaniu wiedzy i informacji (Sætre T. P., Willars G. 2003, s. 13) na miarę zmieniającej się w szybkim tempie rzeczywistości, w latach 20042006 realizowano w Polsce projekt Internetowe Centra Informacji Multimedialnej $w$ bibliotekach szkolnych i pedagogicznych (Tokarska A. 2013, s. 77-79). Celem projektu było podniesienie jakości kształcenia poprzez wprowadzanie nowoczesnych technik w oświacie. Wyposażono wówczas ok. 15 tys. bibliotek szkolnych w komputery (Tamże, s. 78). Obecnie w porównaniu z 2010 r. komputeryzacja bibliotek szkolnych nie postępuje (por. Tabela 5).

Jak wynika z zestawień, wyposażenie bibliotek szkolnych w komputery nieznacznie pogorszyło się. W 2010 r. średnio na jedną bibliotekę przypadało 3,2 komputera do użytku uczniów, w tym średnio 3,1 była z dostępem do Internetu, a 2,1 miała dostęp do Internetu szerokopasmowego. W 2012 r. wskaźniki te wynosiły odpowiednio 3,0; 2,9; 1,9. Można na tej podstawie wnioskować, że dostęp

\section{Tabela 5. Komputery w bibliotekach szkolnych w latach 2010-2012}

\begin{tabular}{|c|c|c|c|c|c|c|c|c|}
\hline \multirow{3}{*}{ Rok szkolny } & \multirow{2}{*}{\multicolumn{2}{|c|}{ Biblioteki szkolne }} & \multicolumn{6}{|c|}{ Liczba komputerów w bibliotece do użytku uczniów } \\
\hline & & & \multicolumn{2}{|c|}{ Ogółem } & \multicolumn{2}{|c|}{$\begin{array}{l}\mathrm{Z} \text { dostępem } \\
\text { do Internetu }\end{array}$} & \multicolumn{2}{|c|}{$\begin{array}{c}\mathrm{Z} \text { dostępem } \\
\text { szerokopasmowym }\end{array}$} \\
\hline & liczba & różnica & liczba & różnica & liczba & różnica & liczba & różnica \\
\hline 30.09 .2010 & 19832 & - & 63449 & - & 60704 & - & 40734 & - \\
\hline 30.09 .2012 & 19713 & -119 & 58179 & -5270 & 56475 & -4229 & 38393 & -2341 \\
\hline
\end{tabular}

Źródło: oprac. własne na podst. danych MEN, Departament Analiz i Prognoz, 12.02.2014. 
do nowoczesnych technologii w bibliotece szkolnej w ciągu dwóch lat został zahamowany. Nie oznacza to, że pogarsza się ogólnie stan komputeryzacji polskich szkół. W komputery są wyposażane pracownie komputerowe, inne pracownie?. Jednak to w bibliotekach szkolnych uczeń ma szansę na dostęp do komputera w czasie innym niż lekcja, kiedy większość dobrze wyposażonych pracowni jest zamknięta.

Ponadto w 2012 r. odnotowuje się mniej korzystny trend związany z poprawą zasobów bibliotek w szkołach wiejskich w porównaniu z bibliotekami szkół miejskich. Dotyczy to również wyposażenia w komputery. O ile w miastach ogółem na bibliotekę szkolną przypadało 3,9 komputera do użytku uczniów, to na wsi 2,1 . W bibliotece szkoły miejskiej średnio każdy komputer miał dostęp do Internetu, a w bibliotece szkoły wiejskiej 2,0. Dostęp do Internetu szerokopasmowego w miastach był średnio w 3,8 komputera, a na wsi dostęp taki miał średnio tylko 1,1 komputera.

\section{Typologia bibliotek szkolnych w świetle badań własnych}

W literaturze przedmiotu najbardziej znana jest dotychczas typologia bibliotek szkolnych autorstwa Hanny Batorowskiej, która, analizując szereg czynników warunkujących zarówno typ kultury informacyjnej, jak i kultury organizacyjnej bibliotek szkolnych, wyodrębniła następujące typy:

1) biblioteka szkolna - „rezerwuar lektur”, „rezerwuar różności”, wypożyczalnia książek, „depozytariusz dziedzictwa” jako punkt wyjścia do działań innowacyjnych, zmian koniecznych z perspektywy cywilizacyjnych przemian i dynamiki potrzeb edukacyjnych;

2) biblioteka szkolna - Internetowe Centra Informacji Multimedialnej lub bardziej upowszechniona nazwa Multimedialne Centrum Informacji (MCI) to w opinii Batorowskiej ulepszony obecnie typ biblioteki w praktyce szkolnej łączony z wizją bibliotecznego laboratorium komputerowego;

3) biblioteka szkolna - szkolny ośrodek biblioteczno-informacyjny (szkolne centrum Informacji - SCI), wzorujący się na organizacji „biblioteki jakości”, „biblioteki uczącej się” i „biblioteki inteligentnej”, nastawionej na kulturę zadaniową w pracy (efektywność, skuteczność, profesjonalizm, jakość nauczania);

4) biblioteka szkolna jako centrum oświatowe środowiska lokalnego, a zarazem centrum kultury informacyjnej społeczności lokalnej. Jest to typ wzorcowej biblioteki szkolnej możliwy do osiągnięcia w dalszej perspektywie (Batorowska H. 2009, s. 219-276).

\footnotetext{
${ }^{9}$ Pilotażowy program realizowany przez MEN w latach 2012/2013 „Cyfrowa szkoła”.
} 
W przeprowadzonych przez Pracownię Bibliotekoznawstwa BN w drugiej połowie 2012 r. badaniach jakościowo-ilościowych nad modelem obsługi czytelniczej w gminie, przeprowadzonych w sześciu gminach wiejskich czterech województw, w których wizytowano 8 bibliotek szkolnych, autorka wyróżniła następujące typy:

1) biblioteka wycofana na obrzeża życia szkolnego (biblioteka mało doceniana przez dyrekcję, z brakiem nowości wydawniczych, z katalogiem kartkowym, z przeciążoną dodatkowymi obowiązkami bibliotekarką, ale z bardzo dobrą średnią wypożyczeń, dobrym kontaktem z uczniami, rzetelnymi tradycyjnymi formami pracy bibliotekarskiej, biblioteka obecna na stronie internetowej szkoły, utrzymująca, ale nie inicjująca współpracy z biblioteką publiczną, nieregularny zakup nowości za niewielkie kwoty);

2) biblioteka integralnie wpisująca się w misję i życie szkoły (usytuowanie w centrum budynku, obecna we wszystkich dokumentach życia szkolnego, atrakcyjna zakładka na stronie internetowej szkoły, wydaje czasopismo szkolne wspólnie z uczniami, specjalne formy pracy z gimnazjalistami, bibliotekarka każde zastępstwo traktuje jako szansę promowania książek, otwarta na rozmowy na każdy temat z uczniami, stała współpraca z biblioteką publiczną, czytelnictwo na dobrym poziomie, estetyczne wnętrze, nowości, czasopisma, stały dopływ pieniędzy na zakupy);

3) biblioteka ograniczanych czytelnikom szans (najniższe czytelnictwo spośród wszystkich bibliotek, zaniedbane pomieszczenia, książki w szarym papierze, stare czasopisma, wstęp do biblioteki mają tylko dzieci czytające pomimo licznej grupy przedszkolnej; położona w odosobnionej części budynku szkolnego, ale z wysokim stopniem wykorzystania komputerów, skromne, ale stałe kwoty na zakup nowości);

4) biblioteka ukrytego potencjału (prowadzona przez dyrektorki szkół w trzech różnych miejscowościach, ukryty potencjał bądź w poszerzaniu funkcji biblioteki o zadania świetlicy lub izby regionalnej, bądź inwestowanie w aktualnie poszukiwany księgozbiór metodyczny, większe nakłady finansowe świadomie przeznaczane dzięki możliwości podejmowania osobistej decyzji, ograniczany czas pracy biblioteki kosztem innych obowiązków);

5) biblioteka zredukowana (w szkole de facto nieobecna, ponieważ zadanie prowadzenia biblioteki szkolnej zostało powierzone bibliotece publicznej, w statystyce wypożyczeń uczniów dają się obserwować pogłębione kryzysy czytelnicze w kl. IV i po przejściu do gimnazjum, praca bibliotekarek publicznych w szkole w wymiarze 6 godzin tygodniowo mało doceniana przez dyrekcję szkoły).

Podstawą wyróżnienia typów bibliotek szkolnych była analiza dokumentów życia szkolnego (planów rozwoju szkoły, statutów, programów wychowawczych szkół, programów profilaktycznych, planów rozwoju szkoły, kalendarza imprez). 
Ponadto brana była pod uwagę statystyka biblioteki szkolnej (wypożyczenia, księgozbiór, regulaminy bibliotek, sprawozdania). Wizyty w szkołach miały charakter studyjny, przeprowadzono w każdej wywiad z dyrektorem, nauczycielem informatyki i języka polskiego oraz z bibliotekarką szkolną (były to tylko nauczycielki). Przeprowadzono badania ankietowe w grupie 133 uczniów VI klas szkół podstawowych i 93 gimnazjalnych z analizy których bezspornie wynika, że biblioteka szkolna jest bardzo ważnym miejscem w doświadczeniach badanych uczniów. Dotyczy to zarówno życia w obrębie szkoły, jak również w porównaniu do kontaktów młodych respondentów z innymi bibliotekami, postrzeganymi w bliskim i dalszym otoczeniu. Jednak w zależności od typu szkoły oraz wieku badanych ta prawidłowość występuje z różną intensywnością ${ }^{10}$.

Zaproponowana na podstawie przeprowadzonych badań własnych typologia bibliotek może być przykładem bardziej szczegółowej charakterystyki dwóch typów bibliotek szkolnych w modelu Batorowskiej, czyli biblioteki „rezerwuaru lektur" i ICIM. Nie odgrywa tym samym uniwersalnej roli diagnostycznej, sygnalizuje jedynie możliwe znaczne zróżnicowanie bibliotek szkolnych w obrębie wskazanego powyżej kanonicznego modelu. W Załącznikach 1 i 2 autorka prezentuje wybrane czynniki ilościowe i jakościowe, które brano pod uwagę w zaprezentowanej autorskiej typologii.

\section{Wnioski}

Wiedza o bibliotekach szkolnych w Polsce jest niewystarczająca. Prezentowany w tekście zasięg danych (w porównaniu z innymi typami bibliotek) uniemożliwia sporządzenie pełnej diagnozy ich stanu. Planowane w tzw. nowym SIO gromadzenie informacji o bibliotekach szkolnych polepszy tę sytuację tylko w częściowym zakresie, z pewnością niewystarczającym wobec obecnych potrzeb całościowej wiedzy o poziomie zainteresowania książką społeczeństwa polskiego.

Nowy zakres informacji dotyczących bibliotek szkolnych (oprócz danych uwzględnionych w niniejszym raporcie) dotyczyć będzie przede wszystkim: stanu księgozbioru (struktura 8 kategorii zbiorów bibliotecznych); liczby korzystających z biblioteki szkolnej użytkowników w niej zarejestrowanych i czytelników wg 4 kategorii wiekowych oraz szczegółowych danych o nauczycielach bibliotekarzach (szereg uszczegółowień, m.in. staż pracy, wykształcenie, kwalifikacje pedagogiczne i inne, rodzaj i wymiar obowiązków).

Pominięcie danych o: skali wypożyczeń, wpływach (zakupie nowości, darowiznach), godzinach pracy bibliotek, liczbie miejsc w czytelniach, liczbie ubytkowa-

${ }^{10}$ Więcej piszę o tym w pracy „Model obsługi czytelniczej w gminie”, która pod redakcją B.Budyńskiej została przygotowana do druku w Bibliotece Narodowej w 2014 roku. 
nych książek, formach pracy nie ułatwi pełnej i systematycznej obserwacji bibliotek szkolnych. Oznacza to konieczność poszukiwania innych (niż poprzez SIO) dróg pozyskiwania istniejących już w statystykach szkolnych danych na temat bibliotek szkolnych. Może to być ankieta przeprowadzana drogą internetową za zgodą MEN i przy zaangażowaniu kuratoriów oświaty w ustalonej cezurze (np. co 3 lata). Zainicjowanie takiej procedury badawczej pozwoliłoby na otrzymanie porównawczych danych o stanie bibliotek szkolnych, a tym samym byłoby podstawą do podejmowania ważnych decyzji o koniecznych programach wspierających ich funkcjonowanie.

Systematyczne zbieranie danych o bibliotekach szkolnych może nie tylko ułatwić decydentom przyjęcie programu naprawczego bibliotek szkolnych, wyznaczyć pożądane kierunki zmian. Jest przede wszystkim potrzebne samym bibliotekarzom jako punkt odniesienia w standardach pracy.

Brak pełnej sieci bibliotek szkolnych w szkołach dla dzieci i młodzieży jest poważnym mankamentem procesu kształcenia i realizowania podstawy programowej. Środowiska szkolne pozbawione biblioteki szkolnej i z różnych powodów niemogące jej utworzyć, powinny być zobowiązane do ścisłej współpracy z bibliotekami publicznymi w celu kształtowania zakupów książek i udostępniania usług bibliotecznych. Szansą powodzenia tej współpracy byłaby propozycja rozbudowania rządowego programu zakupu nowości. Jak wynika z badań nad modelem obsługi czytelniczej prowadzonych w Pracowni Bibliotekoznawstwa IKiCz (o których wspominałam wcześniej), w wielu środowiskach brak jest współpracy pomiędzy biblioteką szkolną a publiczną lub jest ona niewystarczająca, co może negatywnie rzutować na jakość wywiązywania się z zadań wspierania i rozwijania zainteresowań czytelniczych uczniów polskich szkół.

Sytuacja bibliotek w polskich szkołach jest zróżnicowana pod wieloma względami: dostępu uczniów szkół różnego typu do biblioteki szkolnej - co dziesiąte gimnazjum i co ósme liceum nie ma biblioteki szkolnej ani dostępu do niej; warunków pracy bibliotek szkolnych w środowiskach na obszarach wiejskich i w miastach - sytuacja zdecydowanie gorsza dotyczy pierwszej grupy; zasobów bibliotek szkolnych - w gorszej kondycji są biblioteki w szkołach podstawowych i gimnazjach; komputeryzacji - gorzej wyposażone w komputery są wiejskie biblioteki szkolne.

Widoczny jest brak wyraźnej tendencji progresywnej w zasobach bibliotek szkolnych w porównaniu z rokiem 2010, jednakże istnieje możliwość zmiany tej sytuacji, biorąc pod uwagę wspomniane wcześniej plany dofinansowania placówek ze strony MKiDN i MEN. 


\section{Bibliografia}

Batorowska H. (2009), Kultura informacyjna w perspektywie zmian w edukacji, Warszawa, Wydaw. SBP, ISBN 978-83-61464-10-5

Biblioteki Publiczne w Liczbach (2012), (maszynopis)

Informacje i Aktualności [w:] Ministerstwo Edukacji Narodowej [online], [dostęp:

02.03.2015], dostępny w Internecie: <http://men.gov.pl/pl/ministerstwo/informacje/page/6>

Piotrowska E., Rosiek S. (red.) (2012), Raport o sytuacji książki w Gdańsku. Biblioteki i czytelnictwo 2010-2011 [online], Gdańsk, Fundacja Terytoria Książki, [dostęp: 29.08.2014], dostępny w Internecie: <http://www.gdansk,pl_46247.pdf>

Programy i ustugi [w:] Ministerstwo Edukacji Narodowej [online], [dostęp: 02.03.2015], dostępny w Internecie: <http://www.bn.org.pl/programy-i-uslugi/program-zakup-nowosci-wydawniczych-do-bibliotek/2014-priorytet-2>

Raport o stanie edukacji 2012. Liczq się efekty (2013), Warszawa, Instytut Badań Edukacyjnych, ISBN 978-8361693-14-7

Raport o stanie bibliotek resortu Oświaty $i$ Wychowania (1978), Warszawa, Ministerstwo Oświaty i Wychowania, Departament Organizacji Badań i Prognoz Oświatowych, Rada ds. Bibliotek i Informacji. Rok szkolny 1977/78

Sætre T. P., Willars G. (oprac.) (2003), Biblioteki szkolne. Wytyczne IFLA-UNESCO, Warszawa, Wydaw. SBP, ISBN 83-87629-97-9

Stan bibliotek resortu oświaty i wychowania w 1986 r. i ich zadania na lata 19871990 (1987), Warszawa, Ministerstwo Oświaty i Wychowania, Departament Organizacji Badań i Informacji Pedagogicznej

Staniów B. (2012), Biblioteka szkolna dzisiaj, Warszawa, Wydaw. SBP, ISBN 97883-61464-65-5

Tokarska A. (2013), Typologia i misja bibliotek w kontekście historycznym [w:] Tejże (red. nauk.) Bibliotekarstwo, Warszawa, Wydaw. SBP, s. 66-89

Ustawa z dnia 25 października 1991 r. o organizowaniu i prowadzeniu dziatalności kulturalnej, Dz. U. 1991, nr 114

Ustawa z dnia 26 stycznia 1982 r. Karta Nauczyciela, Dz. U. 1982, nr 3

Ustawa z dnia 7 września 1991 r. o systemie oświaty, Dz. U. 1991, nr 95

Zarzadzenie Ministra Edukacji Narodowej z dnia 4 czerwca 1997 r. w sprawie liczby uczniów, na których przystuguje etat nauczyciela bibliotekarza, Mon. Pol., 1997, nr 36, poz. 348 


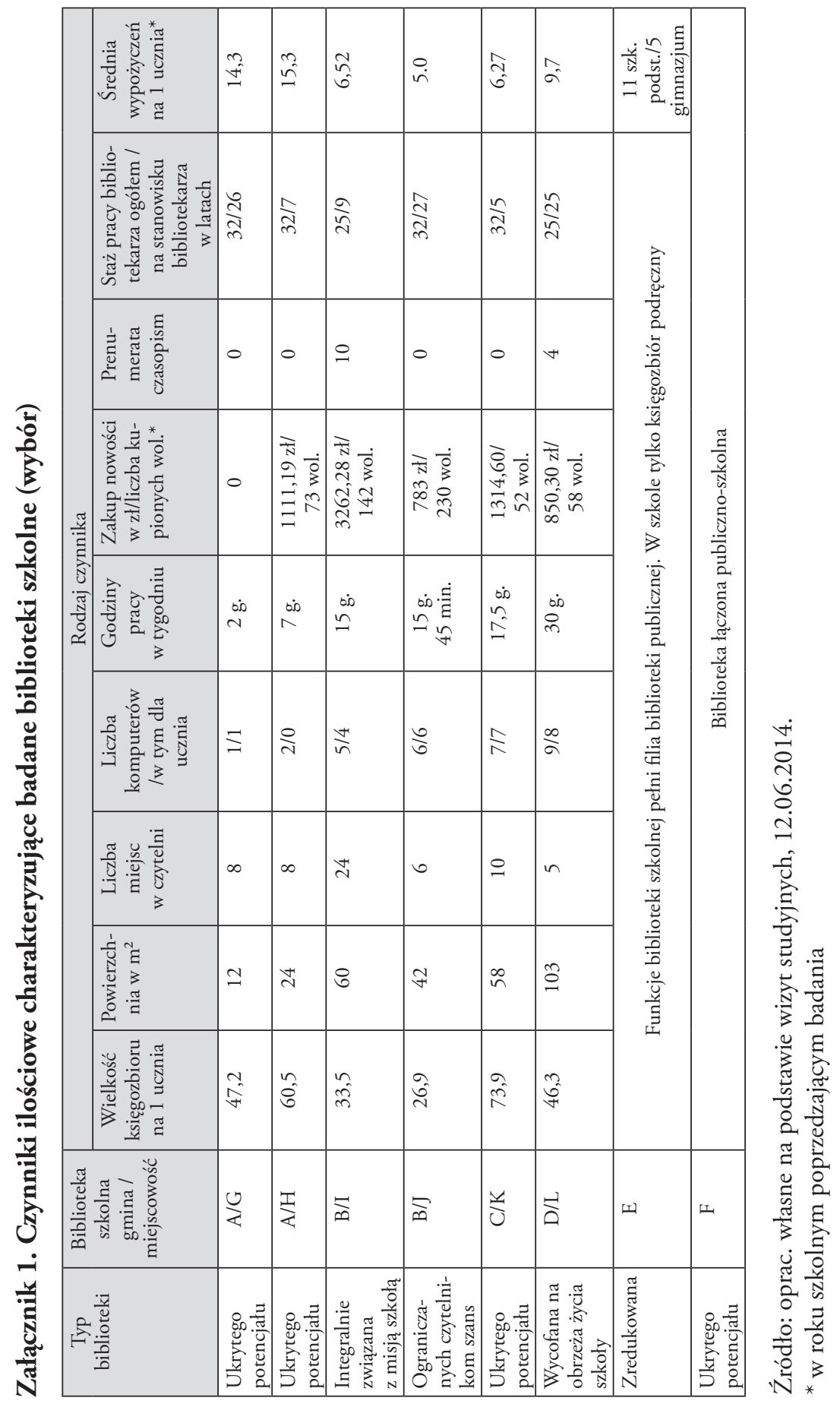




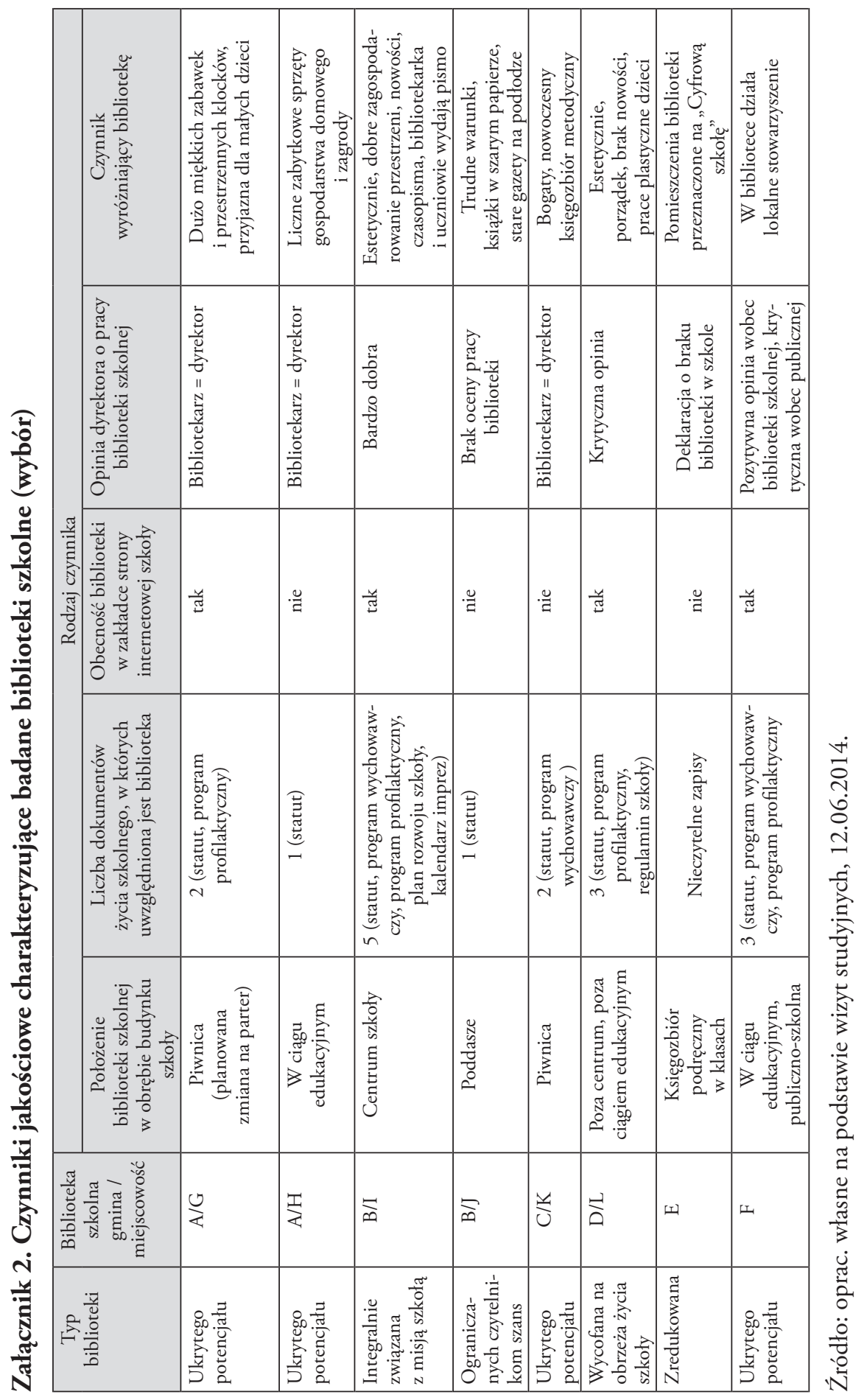




\begin{abstract}
Abstrakt
W artykule zaprezentowano najnowsze dane statystyczne dotyczące bibliotek szkolnych w Polsce na podstawie informacji z Systemu Informacji Oświatowej na tle podstawowych wskaźników, takich jak: sieć bibliotek w polskich szkołach, średnia powierzchnia, średnia wielkość księgozbioru, komputeryzacja. Autorka ponadto przedstawiła i scharakteryzowała kilka głównych typów bibliotek. W tekście zaprezentowano wyniki ankiet przeprowadzonych na temat wykorzystywania potencjału bibliotek szkolnych przez uczniów VI klas szkoły podstawowej i II gimnazjalnej. Podsumowanie stanowi ocena szans i zagrożeń bibliotek szkolnych.
\end{abstract}

\begin{abstract}
The article presents the newest statistical data on school libraries in Poland based on the System of Information on Education. Results are based on research conducted in rural districts of Poland in 2012. Findings refer to such factors as: network of the libraries in Polish schools, average area of school libraries, average size of book collection and computerization. The author presents profiles of five main types of libraries. In addition, paper contains the results of the survey conducted among pupils of primary (6th class) and secondary schools (2nd class) concerning the ability to take advantage of the school libraries' potential. In conclusion author focuses on evaluation of the chances and risks concerning school libraries.
\end{abstract}

